\title{
Yoga Concepts in Real Life
}

\author{
Article by Anitha Bobba \\ Ph.D in Alternative Medicine, History \& Philosophy of an Alternative Medicine, \\ Major Yoga Concepts in Real life, India \\ Email: acunaturecare@gmail.com
}

\begin{abstract}
The process of individual spirit Union with the Supreme Being, or any practice that makes such union is expounded by Sage Patanjali. Here are 10 major concepts associated with Yoga which can be implemented for overall quality of our life style in real world (Fitness Health, 2016).
\end{abstract}

\section{Yoga concepts}

\section{Karma}

This concept refers to any type of mental or physical action which deals with consequences of each action. We can expect every action that you force on another person can be expected in our future life.

Past karmas have effect on current life, overlapping into your present and effecting your present. Actually it is us effecting our reality creating by doing that creating from past (wisdomsdoor, 2016). As past karmas have effect on current life, in order to undo all karmic knots that we have made over the years need to use Worming technique. With vigilant use of Worming Technique, we can take seven year karmic period to one year. This creeping-in reminds you of past actions, so that you can gauge your future actions in accordance with Universal Laws.

According to Indian spirituality karma is a physical, mental, verbal and social activity which has impressions which cannot be erased before creating reaction. Contemplation on Karma principle finds unity with cosmic law by Meditating on idea of cosmos as a doer causing positive effects in Cosmos, see yourself in every being. Personal effort is required the concept of karma can't be experimented to find out workings of Law of Karma (Coghlan\&Miller, 2014).

As Karma is a physical, mental, verbal and social activity which has impressions and which cannot be erased before creating reaction. To work for selfish reasons as to get stature in society leads to bad karma this will restrict one to grow spiritually. Good Karma advances through knowledge and helps in getting job done in selfless manner. One who does his daily duties in tune with nature will have Good karma which in turn leads to God realization (Kramer, 2011).

\section{Dharma}

This concept deals with correct way to live our life and receive good karma. This concept also helps to achieve enlightenment and union with supreme power.

The concept of Dharma in Indian philosophy and religion has multiple meanings depending on the various religions; in common it means 'right way of living and path of righteousness' (Wikipedia, 2016). This right path shows way to right living to the people as per Universe and provide guidance to them. Similarly if it is not supported according to the nature or Universe these differences in laws cause opposite reaction by leading to accumulation of bad karmas. Also multiple religions even though base is common, due to misinterpretation of their religious laws are leading to lot of confusion.

The Research done among Pasters and Hindu leaders by using methodology called Ethnography whose main focus is to understand perceptions, views, fears and aspirations in 
Texila International Journal of Medicine

Volume 4, Issue 2, Dec 2016

divergent cultural context of India. Example of Sanata Dharma is they may participate in multiplicity of truths but they must participate in common duties of Dharma (James, 2010).

In the modern world people are not thinking about Dharma which are the root cause for all sufferings. In reality people who follow Dharma will never fail in anything in the world. The person who follows Dharma realizes Self, under the nature and does all works perfectly with broad ambition and lives a full life with success. Everyone should follow the four fold path; life means existence, knowledge, bliss and absolute, in order to have completeness or fulfillment in life. In practical life one should avoid clashes and create remarkable changes in life for betterment of world and to achieve one human world with peace, unity and international brotherhood (Ramesh, 2006).

\section{Manah}

This concept is word for your Mind. The Manah is the portion of Mind which receives sensory signals from other portions of the body. This is the metaphysical ability for the mind to receive signals from the spirit.

This concept of Manah is the one of the three fold inner organ - thinking. If we are a good spirit, we will have good thinking and it gives results of Asha, justice and conscience (James, 2011) If we are a evil spirit, we will have evil thinking and it gives results of lie, darkness, bad thinking. Basically the force of light in us needs to fight against the force of darkness in us.

The Manomaya means manah or manas or mind; the mind along with five senses is called Manomayakosa. Meditation, tartak, jap and tanmatra are part of Manomaya Kosa-Sadhana. The study was conducted by Shiram Sharma Acharya conducted study with 30 adolescents. Study concluded that Manomaya kosa sadhana is significantly effective for Mental Health of adolescents which helped in building positive feeling, positive attitude and self confidence (Trivedi, 2014).

The Manah with five senses causes all thoughts which leads to action in real world. Controlling Mind can be done only through Sadhanas like Meditation, tartak and jap. Any human being who want to keep his Mind balance need to practice one of these sadhanas keep Mind under control which in turn leads to regulated and rightful thoughts which are useful to our daily life.

\section{Buddhi}

This concept is intelligence, the conscious ability to be able to understand the concepts which are taught to us. It is also an ability to think situations and to use reason when making decisions which are important.

We need to Buddhi Meditation practice to arise conscious and intuitive powers to understand and override challenges before they manifest we are forever healed (Tiwari, 2012). This concept is Buddhi, can be harmful if it is misinterpreted with the individual thoughts with real intuition. It might lead to wrong direction and the person would lose the real awareness of knowledge.

In Human being the great Cosmic mind or Intelligence or Intelligence like a Cosmic computer and stores memories and impressions and also governs senses. Candace Pert's pioneering research in $20^{\text {th }}$ Century demonstrates how we respond to and experience our world through, our internal chemicals, the neuropeptides and their receptors, manifesting themselves as our emotions, beliefs and expectations influenced through biological under pinning of awareness (Venkateswara, 2015).

"As universe evolves, habits of nature evolve", this idea was presented and developed by Rupert Sheldrake and C.S. Pierre. Lynne Me Taggert and Rupert Sheldrake called mental fields as, view of morphic fields, and also called as Quantum Hologram and this 2way communication done through Agna Chakra (Venkateswara, 2015).

Buddhi is knowledge helps to be smart and intelligent in taking decisions. Buddhi is radius of Atman reflection which gives us the power to discriminate and decide what is good for us 
or not. Buddhi influences in the way we understand and interpret our experiences regulate our lives, relationships, behavior and other activities (Jayaram, 2015).

\section{Samskara}

This concept is translated as memories. Every action whether it is good or bad would create an impression. The negative impressions need to be cleansed to obtain immortality.

This concept clearly mentions that as long as we have Samskaras, we will be getting fresh births, this cycle needs to repeat until all samskars exhausted in order to acquire knowledge of self (Sivananda, 2010). If we have bad samskaras the cycle of transmigration keeps on repeating the final destiny would take longer time to achieve.

Indian Philosophy focus on voluntary action that has not cognized before which is generic consciousness, which a generic animal or a human soul wants food and knows where to look in current life proves rebirth based on goal directed activity requires mental dispositions (Samakaras) formed by previous experience. Xenoglossy is similar example as evidence is restricted (Philps, 2009).

Every action what we do creates an impression (Samskara), not only this life what we had in our previous lives also gets accumulated and comes on the whole we have impact on our current life. One can exhaust these Samskaras through Nirbija Samadhi through seclusion of senses and old Samskaras can be destroyed through Vichara (right enquiry of Supreme Self). Actually they are fried out by Jnana (Sivananda, 2010).

\section{Vasana}

This concept is basically group of impressions of actions or memories (samskaras) based on similarities between them. These groups are active even in unconscious state.

According to Bhagavadgita if one works according to his own Vasana is better, so that it helps in exhausting his own Vasanas. If one fail to follow their own Vasanas, they not only fail to exhaust Vasanas but also add more load of Vasanas due to his temperament (Chinmayananda, 1995).

Samkhya \& Yoga Concepts accept the theory of reincarnation, is collation of Samskaras and Vasanas. Our Actions determine our Personality; each action interacts with previous action and personality changes accordingly. Future actions are also determined by our Personality (Dalal \& Misra, 2012).

The Brahman is the Supreme Self, there is no Vasana in Brahman. The seeds of impure Vasana can be fry up through Nirvikalpa Samadhi. The knowledge of Brahman one can extinct all Vasanas. One who aspires higher spiritual planes of Nirvikalpa Samadhi should approach saints who had achieved that level (Sivananda, 2010).

\section{Kriya}

This concept is actually practice or exercise of the techniques found in Yoga. It pertains to correct physical motions involved and also has the skill involved in correcting the incorrect technique while performing each movement.

The study of Kriya Yoga and brain waves published in 1998 in the Magazine Bindu by Psychologist Erik Hoffman. A Researchs is concept is actually practice or exercise of the techniques found in Yoga. It pertains to correct physical motions involved and also has the skill involved in correcting the incorrect technique while performing each movement. The effects of kriya yoga on the EEG(Electro Encephalography) i.e recording the brain waves before and after Kriya was measured, the result was, there was change in brain waves, the alpha and theta activities increased about $40 \%$. Further research findings were that any Kriya method has no direct effects had been proved wrong; the uninformed debasers feel that Kriya is demoniac (Kinnes, 2014).

The six purificatory excercises of Kriya are Dhauti, Basti, Neti, Nauli, Trataka and Kapalbhati. These purification excercises helps in cleaning up the organs, Digestive, 
Texila International Journal of Medicine

Volume 4, Issue 2, Dec 2016

Respiratory and circulatory systems. If one practices Meditation would keep Brain and Nerves system under control(Sivananda, 2011).

\section{Viveka}

This concept is the ability to realize the difference between reality and fantasy of life. It also realizes temporary aspects of life and the permanent aspects of the current and after life.

This concept of viveka is the knowledge shows the difference between knower and knowable which ends the entire knowledge. Knowable is different from its nature and is revealed by consciousness (Elenjimettam, 1974). If one can't see the difference between the knower and knowledge can't realize the difference between reality and fantasy of life.

The Yogic intellectual capacity of Vivek Buddhi (discriminative wisdom) acts as a way to enhance authenticity. In the real world, the ability to concept is the ability to manage wisdom is emotional intelligence. In psychotherapy is often to help clients determine the meaning \& significance of their feelings (Marques\&Dhiman, 2016). One can achieve Viveka meditaion on OM, by doing Nishkamya Karma.

\section{Viragya}

This concept concerns with disinterest anything in current life. This concept expects distance yourself from anything you enjoy in mortal life in order to prepare for after life.

The Viragya means non-attachment and Mind can be controlled by practice and nonattachment. When we can understand Nitya and Anitya, Dharma and Adharma, then Viragya develops through which we can have control of our Mind (Nikhilananda, 2016).

If we have attachment to worldly things, then Viragya can't be developed and can't understand the reality.

This concept expects distance yourself from anything you enjoy in mortal life in order to help other needy people. One should experience in pure giving, for example Traditional healers describes cures for diseases like depression, angst or Vairagya. The UN Holloway's ideas are for resources mobilization is an ongoing and evolving process (Holloway, 2014).

One can achieve Viveka and Vairagya by Chitta-Suddhi. The Chitta-Suddhi is done by Nirguna Dhyana, meditaion on OM, by doing Nishkamya Karma. Along with this approach Sadguru for guidance, by doing this one would realize Vedantic realization which comes through Nididhayasana (Sivananda, 2011).

\section{Sanyasa}

This concept attempts to sum up all of other Yoga concepts which contribute to a well led life. It is the eventual perfection in all aspects of life to attain perfect and healthy after life.

The real meaning of Sanyasa is sacrificing oneself for the sake of doing something, for this you need not be single, you can be householder and still perform the duties of mankind. The aim of Sanyasa is not moksha, doing seva, selfless service. If everyone cultivate the habit of selfless service world would be a peaceful place to live (YOGA, 2016).

On the contrary, if a person is greedy and selfish and act to the world that he is real Sanyasa, he misleads people, so one should be careful in approaching him.

The Sanyasa of Gita will not tolerate complete cessation of activity. All research will be useless if internal research is not allied (Gupta, 2016). Sanyasa means end of life each stage prepares for next stage.

This concept attempts to sum up all of other Yoga concepts which contribute to a well led life, in order to achieve this one should sacrifice oneself for sake of doing something for others or to the world. The modern society should adapt the above concepts to attain Oneness of Mankind (YOGA, 2016).

The Mastery of Mind leads to renunciation (Sanyasa) of all. Renunciation means abnegation of mind from all desires and egoism through which one acquires immortality in life, oneness of all in Brahman. Keep the mind always rooted in God amidst of all activities of life by having confidence in your own faculties and powers (Sivananda, 2011). 


\section{Conclusion}

The Good Karma leads to good Samskaras, one who does his duties according to nature will have good karma. One needs to follow Dharma of God (Divine) in order to follow one human world and to maintain International brotherhood. The Mind has to be zero, in order to achieve truth and rightful thoughts which influences Buddhi through which we understand and experience our lives spiritually and worldly.

The Kriya is used to keep our physical body under healthy condition which acts like a Temple to hold the Atman. All the Samskaras and Vasanas which are the root cause of Avidya needs to be removed by either by undergoing experience (Bhoga) or fried in "Yoga Fire” or can be done both. Samskaras can be scraped by Sahaj Marga Raja Yoga meditation from casual body through Transmission of Pranahuti by Guru (Divine Force of power), then only Supreme Self (Brahman) remains. All the spiritual stages are passed on without even realizing them and achieve the highest spiritual state in this life time itself. One attains renunciation (Sanyasa) from egoism and all desires, finds oneness of all in Brahman, and develops cosmic love for all living beings.

Actually practicing Sahaj Marga Raja Yoga meditation is my own experience. When one Atman is found in all living beings, all life is one. The whole world is one family of God. By living spiritually doesn't mean we run away from our duties of family. We need to live like birds with two wings one with Spiritual life and Worldly life to live peaceful and blissful.

\section{References}

[1]. Chinmayananda, S. (1995). The Holy Geeta from

https://books.google.co.in/books/about/The_Holy_Geeta.html?id=eVw_Rff7m7AC

[2]. Coghlan, D., \& Miller, M.B. (2014). The Sage Encyclopedia of Action Reserach from http://www.ebook777.com/sage-encyclopedia-action-research/

[3]. Dalal, A.K., \& Misra, G. (2012). New Directions in Health Psychology from https://books.google.co.in/books?id=1l_lDAAAQBAJ\&pg=PT215\&lpg=PT215\&dq=current+research +activities+Vasanas\&source=bl\&ots=b25a45RqHZ\&sig=Vwf7iNXsBRwZizNEBp9kHAujmds\&hl=en \&sa=X\&ved=0ahUKEwjj75OStI7QAhUKN48KHZFrCZQQ6AEIITAC\#v=onepage\&q=current\%20re search\%20activities\%20Vasanas\&f=false

[4]. Elenjimettam, A. (1974). The Yoga Philosophy of Patanjali from

https://books.google.co.in/books?id=E8jWAAAAMAAJ

[5]. Fitness Health. (2016). Concepts of Yoga from

http://www.fitnesshealth101.com/fitness/yoga/concepts

[6]. Gupta, P. (2016). Wisdom of $\quad$ P. $\quad$ Kalam

https://books.google.co.in/books?id=anhQihB4lKsC\&pg=PA44\&lpg=PA44\&dq=wisdom+of + kalam\& source=bl\&ots=_ylGseTnKC\&sig=_iZhXeQW2U9XKiT7QJzDc5zN3vU\&hl=en\&sa=X\&sqi=2\&ved= 0ahUKEwjsl-

yHuo_QAhXJuo8KHeufCkwQ6AEIUTAM\#v=onepage\&q=wisdom\%20of\%20kalam\&f=false

[7]. Holloway, R. (2014). Towards Financial Self reliance from https://books.google.co.in/books?id=ypRAwAAQBAJ\&pg=PP1\&dq=Towards+financial+self + reliance\&hl=en\&sa=X\&ved=0ahUKEwi96cL JmY_QAhWIM48KHXaYCSkQ6AEIGjAA\#v=onepage\&q=Towards\%20financial\%20self\%20relianc $\mathrm{e} \& \mathrm{f}=\mathrm{false}$

[8]. James, L. (2011). Philosophy: An introduction to the Art of wondering from https://books.google.co.in/books/about/Philosophy_An_Introduction_to_the_Art_of.html?id=8vw9z_m nzH8C\&redir_esc $=y$

[9]. James, J.D. (2010). McDonaldisation, Masala McGospel and Om Economics from https://in.sagepub.com/en-in/sas/mcdonaldisation-masala-mcgospel-and-om-economics/book235557

[10]. Jayaram, V. (2015). What is Buddhi? From

http://www.hinduwebsite.com/hinduism/concepts/buddhi.asp

[11]. Kinnes, T. (2014). Kriya Research Findings from http://oaks.nvg.org/kresearch.html

[12]. Kramer, S. H. (2011). Karma Yoga and Practical Spirituality from http://www.susankramer.com/KarmaYoga.html 
Texila International Journal of Medicine

Volume 4, Issue 2, Dec 2016

[13]. Marques, J, \& Dhiman, S. (2016). Leadership Today: Practices for Personal and Professional Performance

https://books.google.co.in/books?id=2LnmDAAAQBAJ\&pg=PA91\&lpg=PA91\&dq=current+research +activities+Vivekam\&source=bl\&ots=QGphLJCmjj\&sig=3fjFVTSOMo_gxRabNfcM0dZ6aEo\&hl=en $\& s a=X \& v e d=0$ ahUKEwjGve6k9o7QAhUIL48KHUbXB1QQ6AEIKDAC\#v=onepage\&q=current\%20 research\%20activities\%20Vivekam\&f=false

[14]. Nikhilanda, S. (2016). Restraining Mind through Abhyasa and Vairagya from http://www.chinmayamission.com/restraining-mind-abhyasa-vairagya/\#.WBhWOtIrLIU

[15]. Philips, S.H. (2009). Yoga, Karma, and Rebirth: A Brief History and Philosophy from http://www.jstor.org/stable/10.7312/phil14484

[16]. Ramesh, T.A. (2006). Dharma and the Modern World from http://www.boloji.com/index.cfm?md=Content\&sd=Articles\&ArticleID=2583

[17]. Sivananda, S. (2010). Samskaras from

http://sivanandaonline.org/public_html/?cmd=displaysection\&section_id=871

[18]. Sivananda, S. (2010). Vasanas from http://sivanandaonline.org/public_html/?cmd=displaysection\&section_id=884\&format=html [19]. Sivananda, S. (2011). Kriya Yoga Sadhana from http://sivanandaonline.org/public_html/?cmd=displaysection\&section_id=526\&format=html [20]. Sivananda, S. (2011). Jnana Yoga Sadhana from http://sivanandaonline.org/public_html/?cmd=displaysection\&section_id=1225\&format=html [21]. Sivananda, S. (2011). True Renunciation from http://sivanandaonline.org/public_html/?cmd=displaysection\&section_id=560\&format=html [22]. Trivedi, I. (2014). Impact of Manomaya kosh sadhana on Adolescent's Mental Health from http://www.jiarm.com/July2014/paper15812.pdf

[23]. Tiwari, M. (2012). Women's Power to Heal: Through Inner Medicine from https://books.google.co.in/books/about/Women_s_Power_to_Heal.html?id=DHNMxjGnqzQC\&redir_e $\mathrm{sc}=\mathrm{y}$

[24]. Venkateswara, R.K. (2015). Oneness in Science and Spirituality from https://books.google.co.in/books?id=lrhcDQAAQBAJ\&pg=PT69\&lpg=PT69\&dq=current+research+a ctivities+Buddhi(knowledge)\&source=bl\&ots=p4dw294x5I\&sig=x-snJZqJCjyB4hlSXBj3-

46v5gQ\&hl=en\&sa $=X \& v e d=0$ ahUKEwj4zK-

N84zQAhXLL48KHdZSDLwQ6AEIPDAH\#v=onepage\&q=current\%20research\%20activities\%20Bud dhi(knowledge)\&f=false

[25]. YOGA. (2016). Magazine of Bihar School of Yoga published in 1963 from http://www.yogamag.net/archives/2008/lnov08/san.shtml

[26]. Wisdomsdoor. (2016). Karma: Why does it exist? And How can you control it? From http://www.wisdomsdoor.com/rc4/hrc4-05.php

[27]. Wikipedia. (2016). Dharma: from https://en.wikipedia.org/wiki/Dharma 